\title{
Teacher Training: a Dilemma in Deeni Madaras from Student's Perspective.
}

\author{
Misbah Akhtar ${ }^{1}$ DrNaveed Sultana ${ }^{2}$ \\ ${ }^{1}$ Lecturer Department of Education .The Islamia University of Bahawalpur, Pakistan \&MPhil scholar of Allama \\ Iqbal Open University Islamabad, Pakistan \\ ${ }^{2}$ Assistant Professor Department of Elementary \&Teachers Education. Allama Iqbal Open University, \\ Islamabad, PakistanCorrespondence: Misbah Akhtar.Lecturer Department of Education .The Islamia \\ University of Bahawalpur, Bahawalnagar Campus. District Bahawalnagar. Pakistan.
}

\begin{abstract}
The main focus of the article was to analyze the performance of the teachers in Deeni Madaras regarding competencies for using effective teaching skills at middle level (vustani).For this purpose opinion of studentsof Deeni Madaras were obtained and structured observation was used. For this purpose sample of 204 participants was selected. A questionnaire on five likert scale was used for data collection. Data collected by questionnaire and observation was analyzed through percentages. It was concluded that there teachers of Deeni Madarasdon't plan lesson, don't use AV aids. They need training for lesson planning, appropriate use of punishment, use of motivational techniques, use of $\mathrm{AV}$ aids in the class room and using of teaching methodology.
\end{abstract}

Key Words:-Deeni Madaras, Need Assessment, Teaching Skills.

\section{INTRODUCTION}

In any country education system plays a role of back bone. In Pakistan formal system is running to educate the people. Beside this formal system of Madaras education is also a source to provide education in Pakistan. In spite of the fact that they are self governing, the increase in the number of religious institutions in Pakistan has been extra-ordinary as exemplified by the statistical data collected through the Statistics Division, Government of Pakistan. As beginning with only 245 institutes at the time of independence of Pakistan in 1947, the number has risen to over1 1491 by 2005 out of which 7948 are registered whereas 3543 are non-registered. Out of 11491 madars, 1815 are for girls, 3925 for boys and 5751 offer co-education (www.statpak.gov.pk/depts/fbs/publications/nec2005/nec46). Dr .MasoodaBano has mentioned that the number of Madaras in 2007 were 16000.After 9/11 Deeni Madaras got too much attention. It was particularly noted that in spite of the fact that Madaras increased but quality education was not provided there.

For the development of any society education plays a vital role and quality education depends on different factors such as objective, curriculum, teachers training of teachers and heads, research, job, research and examination(Sultana,2004).Teacher training is very important for the professional growth of the teachers either teachers belongs to formal system of education or informal. In formal system of education pre service and in-service teachers training program are presented in Pakistan such as PTC ,CT ,BE.dBS.Ed, ME.d and MA education .Teacher training in Pakistan is suffering a lot of problems especially it got much importance in Deeni Madaras after 9/11. (Akhtar, Din, \& Iqbal, 2011) concluded that in Deeni Madaras there is dire need of trained teachers. Madaras lack in fundamental amenities, resources, provision and use of latest technology in class room teaching, job opportunities, adequate research work and especially teacher training.

Pakistan Economic Survey (2008) has mentioned that to bring formal education and Deeni Madaras closer to each other different reforms programs has been initiated including formal education in 8000 Madaras , salaries to teachers, provision of grants ,teachers training and equipment. TEVTA Punjab has planned to train the teachers and established Government Technical Institute at 27 Deeni Madaras including 20 for male 5 for female and 2 mixed MadarasIqbal and Safiana(2005) held a research to review problems of teacher education in Pakistan. During the literature review it was found that teaching is a skill and an art and cannot be measured in short time, curricula for teacher training programs does not match the needs of society and recent world, inadequate qualification and lack of experience of teachers trainers, lack of research in the area of teacher education and poor quality of teacher education program results in failure of achievement of objectives of quality education. From this study it was concluded that duration for teacher education program and teaching practice should be extended, community participation, making teaching profession charming, increase in grant for education up to at least $4 \%$ and provision of guidance to trainee teachers to use different skills as using different methods in class room, how to gain attention of students in class room, how to start lesson and use of 
innovative approaches during teachers training.Sultana (2004) held a study to assess need and designing a model for professional development of college teachers in Pakistan. From this study it was concluded that teachers don't use examples, illustrations and visuals to clarify the lesson, deficiency of motivational and attention gaining devices in the class room, lack of usage instructional technology and teaching methods to boost up learning, unawareness of teachers about the educational objectives pointed out in education policies and curriculum development, Lack of attention on character building of the college students and critical thinking and shortage in the usage of different evaluation techniques. Kronstadt K.A (2009) said in his article "Education Reform in Pakistan" that in December 2001, the government launched an education sector reform in which stress was given on teacher training. Besides teacher training need in Madaras emphasis was also given to national literacy rate, providing universal education quality through curriculum reform and assessment reforms. Hussain and Qureshi(2007) have conducted a descriptive study of Madrasa Education in Pakistan. They have tried to explore the issues and problems of Madrasa Education in Pakistan offering a historical back ground to the current scenario, but their study focuses more on historical development of Madaras related issues and they fail to base their suggestion on empirical data. Regarding the teacher training they discussed that in Madaras the content of training material seems duplication of old teacher training institution training material with reduction of some contents and parts regardless of stated training objectives.

In reference of teacher training emphasis is also given on teacher training in different educational policies. In national educational policy (1998-2010) it was discussed to increase the effectiveness of the system by institutionalizing in service training of teacher trainers and educational administrators through school clustering and other techniques. In this policy it was also discussed that content and methodology part of teacher education will be revised. This study was conducted to examine the competencies of Deeni madaras teachers for using effective teaching skills for effective learning at middle level in District Bahawalnagar from student's point of view.

\section{METHODOLOGY}

The mixed method of research was adopted by the researcher. Questionnaire and observational technique was used as a tool of research. Researcher used observational technique and observes ten madaras for ten days.

\subsection{Population}

In District Bahawalnagar there were 637 Deeni madaras. Out of these '267 were masajid cum Deeni madaras and 370 were purely Deeni Madaras. The focus of suggested study was purely on Deeni Madaras. All 370 madaras of District Bahawalnagar, out of which 297 are for boys, 44 for girls and 29 mixed. All students of these Deeni Madaras comprised the population of the study.

Table 2.1 Detail of Total Number of Deeni Madaras, Teachers and Students in District Bahawalnagar

\begin{tabular}{|l|l|l|l|l|l|}
\hline $\begin{array}{l}\text { Sr } \\
\text { No }\end{array}$ & Tehsil & No of Deeni Madaras & \multicolumn{2}{|l|}{ No of Teachers } & No of students \\
\hline & & & Permanent & Temporary & \\
\hline 1 & Bahawalnagar & 135 & 244 & 36 & 8951 \\
\hline 2 & Chishtian & 86 & 176 & 23 & 5952 \\
\hline 3 & Fortabbas & 52 & 73 & 5 & 2392 \\
\hline 4 & Haroonabad & 49 & 89 & 17 & 3321 \\
\hline 5 & Minchanabad & 48 & 89 & 4 & 2831 \\
\hline $\mathbf{6}$ & Total & $\mathbf{3 7 0}$ & $\mathbf{6 7 1}$ & $\mathbf{8 5}$ & $\mathbf{2 3 4 4 7}$ \\
\hline
\end{tabular}

Source: Industries Department, District Bahawalnagar, Pakistan2.1.1Sampling:

By applying stratified sampling two strata were selected. One stratum was for girls and one for boys. A sample consisting of 204 students of Deeni madaras were selected randomly from five tehsiles of District Bahawalnagar. From each tehsil 7 Madaras were selected by using stratified sampling, out of which 5 madaras were of boys and 2 of girls as there were less no of girls Madaras in District Bahawalnagar as compared to boys were selected. Only from tehsil Fortabbas six madaras, 5 madaras were of boys and one for girls because of noncooperated attitude of mohatamam. Some Madaras refused to allow the researcher's access to their students and teachers. So those Madaras were eliminated from the respondents' list and the remaining Madaras were further randomly selected. Then from each madrasa 6 students were selected randomly. The researcher personally

DOI: $10.9790 / 0837-2108054347 \quad$ www.iosrjournals.org $\quad 44 \mid$ Page


visited five tehsiles of District Bahawalnagar i-e Fortabbas, Haroonabad, Minchanabad, Chishtian and Bahawalnagar, distributed questionnaires and got immediate response from respondents. Due to personal visit of researcher mostly respondents responded positively.

\section{Analysis of data:}

\begin{tabular}{|c|c|c|c|c|c|c|}
\hline \multicolumn{7}{|c|}{ Table 3.1Analysis of Student's responses } \\
\hline $\begin{array}{l}\text { SR } \\
\text { NO }\end{array}$ & Statement & S A & A & UN & D A & S D \\
\hline 1 & $\begin{array}{l}\text { Teachers come to } \\
\text { madrasa regularly }\end{array}$ & 91.18 & 6.86 & & 1.47 & 0.49 \\
\hline 2 & $\begin{array}{l}\text { Teacher comes to class in } \\
\text { time. }\end{array}$ & 90.69 & 8.33 & & 0.49 & 0.49 \\
\hline 3 & $\begin{array}{l}\text { Teacher uses charts for } \\
\text { teaching }\end{array}$ & 18.63 & 5.39 & 1.96 & 6.86 & 67.16 \\
\hline 4 & $\begin{array}{l}\text { Teacher uses TV as } \\
\text { instructional aid. }\end{array}$ & 18.63 & 5.39 & 1.96 & 6.86 & 67.16 \\
\hline 5 & $\begin{array}{l}\text { Teachers use computer } \\
\text { for teaching. }\end{array}$ & 1.96 & 3.92 & 1.96 & 2.45 & 89.71 \\
\hline 6 & $\begin{array}{l}\text { Teachers use blackboard } \\
\text { during teaching. }\end{array}$ & 11.27 & 6.86 & 0.98 & 3.92 & 76.96 \\
\hline 7 & $\begin{array}{l}\text { Teachers get angry in the } \\
\text { class. }\end{array}$ & 63.24 & 8.82 & & 2.45 & 25.49 \\
\hline 8 & $\begin{array}{l}\text { You understand what } \\
\text { your teachers say. }\end{array}$ & 65.69 & 30.39 & 0.49 & 0.98 & 2.45 \\
\hline 9 & $\begin{array}{l}\text { Teachers respect other } \\
\text { teachers. }\end{array}$ & 87.75 & 10.29 & & 0.49 & 0.98 \\
\hline 10 & $\begin{array}{l}\text { Teachers show respects to } \\
\text { the students. }\end{array}$ & 90.69 & 8.33 & & 0.49 & 0.49 \\
\hline 11 & $\begin{array}{l}\text { Teachers give weightage } \\
\text { to the opinion of } \\
\text { mohtamam. }\end{array}$ & 81.37 & 15.69 & 0.49 & 1.47 & 0.98 \\
\hline 12 & $\begin{array}{l}\text { Teacher has full } \\
\text { command over subject. }\end{array}$ & 83.82 & 12.26 & 0.98 & 1.47 & 1.47 \\
\hline 13 & $\begin{array}{l}\text { Teachers have contact } \\
\text { with your parents. }\end{array}$ & 82.35 & 12.75 & 0.98 & 2.45 & 1.47 \\
\hline 14 & $\begin{array}{l}\text { Teachers teach you even } \\
\text { if you don't want to } \\
\text { study. }\end{array}$ & 62.25 & 20.59 & 7.84 & 6.86 & 2.45 \\
\hline 15 & $\begin{array}{l}\text { Teachers teach you with } \\
\text { their own will. }\end{array}$ & 71.57 & 16.18 & 0.98 & 3.92 & 7.35 \\
\hline 16 & $\begin{array}{l}\text { Teachers give you reward } \\
\text { when you memorize the } \\
\text { lesson. }\end{array}$ & 70.59 & 10.78 & 1.47 & 3.92 & 12.75 \\
\hline
\end{tabular}




\begin{tabular}{|c|c|c|c|c|c|c|}
\hline 17 & $\begin{array}{l}\text { Teacher delivers lecture } \\
\text { in clear voice. }\end{array}$ & 86.76 & 5.88 & & 0.98 & 6.37 \\
\hline 18 & $\begin{array}{l}\text { Teachers treat equally to } \\
\text { all students. }\end{array}$ & 88.73 & 7.35 & 0.98 & 1.47 & 1.47 \\
\hline 19 & $\begin{array}{l}\text { If you don't learn the } \\
\text { lesson, teachers punish } \\
\text { you by making you stand } \\
\text { in the class }\end{array}$ & 76.47 & 17.16 & 0.49 & 1.96 & 3.92 \\
\hline 20 & $\begin{array}{l}\text { Teachers scold you for } \\
\text { your mistake }\end{array}$ & 88.24 & 7.35 & - & 0.98 & 2.94 \\
\hline 21 & $\begin{array}{lcc}\begin{array}{l}\text { Teachers } \\
\text { physically }\end{array} & \text { punish } & \text { you } \\
\text { mistake. } & & \text { your } \\
& & \end{array}$ & 70.59 & 17.16 & & 1.47 & 10.78 \\
\hline 22 & $\begin{array}{l}\text { Teachers fine you for } \\
\text { your mistake. }\end{array}$ & 38.73 & 17.65 & 0.49 & 3.43 & 39.71 \\
\hline 23 & $\begin{array}{l}\text { Teachers ask reason for } \\
\text { coming class late. }\end{array}$ & 87.75 & 9.31 & & 1.96 & 0.98 \\
\hline 24 & $\begin{array}{l}\text { Teachers encourage you } \\
\text { for asking questions. }\end{array}$ & 75.98 & 16.67 & 0.49 & 1.96 & 4.41 \\
\hline 25 & $\begin{array}{l}\text { Teachers encourage you } \\
\text { to have discussion with } \\
\text { other students. }\end{array}$ & 69.61 & 10.78 & 0.98 & 3.92 & 14.71 \\
\hline
\end{tabular}

It is evident from the table 3.1 that mostly students had opinion that their teachers come to class regularly and they are punctual. Teachers of Deeni madaras show respect for teachers as well as for their students .According to the opinion of students their teachers give weightage to their opinion. Teachers have clear concepts about their subjects and their students understand clearly whatever they teach.On the other side it was found that teachers of Deeni madaras don't use audio visual aids .in some madaras black board was used but other aids like charts and television were not used. Teachers punish their students when they don't do their assignments.Punishment used in madaras is mostly of physical and fine.

\section{Table 3.2 Observation Schedule of Teachers}

It is observed that teachers come regularly and have sufficient knowledge and full command over subject. Mostly teachers use punishment. It was also observed that teachers also encourage students to have discussion with teachers, mostly teachers respect other teachers, teachers have sufficient knowledge about subjects and students like their way of communication. While it was observed that teachers of Deeni Madaras don't give examples from daily life, don't use AV aids, don't plan lesson before going to class and don't use different methods.

\section{CONCLUSIONS AND RECOMMENDATIONS}

It is concluded that teachers of Deeni Madaras are regular and punctual .They respect other teachers and mohtamams, have sufficient knowledge about their subjects. Mostly teacher use autocratic style of teaching, punish their students for mistakes, don't give examples from daily life, don't use AV aids and there is lack of motivational techniques used by the teachers in the class room. It is suggested that teachers of Deemi Madaras should improve different teaching skills like use of AV aids ,planning of lesson before going to school ,use of motivational techniques, use of examples from daily life and use of variety of methods in the class room. There should be teacher training programs for the teachers of Deeni Madaras. This study may also be conducted to take the response of teachers and mohtamams. This study should also be executed on large scale. 


\section{REFERENCES}

[1] Bano, M. (2007). Beyond Politics: the Reality of a Deobandi Madrasa in Pakistan. Journal of Islamic Studies, 18(1), 43-68.

[2] Education, P. M. o. (1998). National Education Policy, 1998-2010: Government of Pakistan, Ministry of Education.

[3] Govt of Pakistan,(2008). Economic Survey 2007-08: Government of Pakistan, Economic Advisor Wing, Finance Division Islamabad.

[4] Hussain, M., \& Qureshi, M. (2007). Madrasah Education in Pakistan: Issues \& Its Effects on Education System

[5] of Pakistan. Journal of Educational Research, 10.

[6] Iqbal, M., \&Sufiana, K. (2005). Some Problem Areas of Teacher Education in Pakistan. Pakistan Journal of Education, 22, 3-11.

[7] Industries Department District Bahawalnagar Pakistan (2010).Data about deeni Madaras. (Unpublished data).

[8] Sultana, N. (2004). Need Assessment and Designing a Model for Professional Development of College Teachers in Pakistan. University of Arid Agriculture, Rawalpindi.

[9] Kronstadt, K.A. (Dec 23, 2004). Education Reform in Pakistan. Foreign Affairs

[10] Division: Congressional ResearchService report of Congress. Code: RS22009.

[11] (www.statpak.gov.pk/depts/fbs/publications/nec2005/nec46). 